\title{
Utsatta barn i \\ familjerättsprocesser: \\ utredares bemötanden och \\ barns strategier
}

MARIA ERIKSSON \& ELISABET NÄSMAN

Sedan början av 1990-talet har en rad förändringar i lagstiftningen genomförts för att stärka barns rätt att komma till tals i familjerättsliga tvister. Hur tillämpas lagstiftarens krav på delaktighet för barn i fall där barnen har en utsatt situation, som när pappa utövat våld mot mamma?

Under 2007 var ungefär 7200 barn och ungdomar i åldrarna 0-17 år föremål för en utredning om vårdnad, boende eller umgänge (Socialstyrelsen 2008). Sedan 1996 åligger det den som vid en rättslig tvist mellan ett barns föräldrar verkställer en utredning om vårdnad, boende eller umgänge att, om det inte är direkt olämpligt, undersöka "barnets inställning" och redovisa den för rätten (Föräldrabalken 6 kap. 19§). Socialstyrelsen konstaterar i sin lägesrapport från 2005 att utredningar om

Maria Eriksson, docent i sociologi, sociologiska institutionen, Uppsala universitet

Elisabet Näsman, professor i sociologi, sociologiska institutionen, Uppsala universitet vårdnad, boende och umgänge har blivit mer komplicerade, "ofta med hög konfliktnivå, familjevåld, sociala problem och psykisk sjukdom. Många barn far illa av att föräldrarna tvistar» (Socialstyrelsen 2006 s. 31). Även 2002 års vårdnadskommitté pekar på stora problem i hanteringen av fall där det finns en historia av våld (SOU 2005:43). Det har länge funnits en begränsad kunskap om vad lagstiftningens krav på delaktighet för barn i familjerättsprocesser betyder för utsatta barn. Vissa relevanta studier har genomförts (t.ex. Cederborg \& Karlsson 2001, Mattsson 1998, Rejmer 2003, Warming 2002), men forskningsbaserad kunskap om villkoren för och utsatta barns upplevelser av mötet med svenska 
vårdnads-, boende- eller umgängesutredare har varit i stort sett obefintlig.

Den här artikeln ska fylla några av dessa kunskapsluckor. Syftet är dels att beskriva hur handläggare av familjerättsliga utredningar kan bemöta barn som upplevt pappas våld mot mamma, dels att beskriva barnens strategier i mötet med utredarna samt i utredningsprocessen i stort. Artikeln bygger på intervjuer med barn i en studie av hur barn med erfarenheter av att pappa varit våldsam mot mamma upplever och hanterar mötet med handläggare inom socialtjänsten som på begäran av domstol genomför en utredning om vårdnad, boende eller umgänge. ${ }^{1}$

\section{Teoretiska och metodologiska utgångspunkter}

Hittills har forskningen om barn som upplever våld i sin familj framförallt tagit sin utgångspunkt $\mathrm{i}$ etablerade teorier om socialisation och/eller barns utveckling, trauma och överlevnad (se Eriksson 2007). Generellt sett har barns egna beskrivningar och tolkningar av våld och/eller sin situation inte varit centrala (Christensen 2002). Idag är dock flera av de aktiva nordiska forskarna på fältet influerade av den "nyau barndomssociologin (t.ex. Cater 2004, Eriksson et al. 2008, Eskonen 2005, Fors-

1 Projektet pågick under 2005-2007 och bestod av två delstudier. Den del som artikeln bygger på finansierades av Brottsofferfonden. I projektgruppen ingick även Gunilla Dahlkild-Öhman, Uppsala universitet, och Jeanette Sundhall, Göteborgs universitet. berg 2005, Solberg 2007). ${ }^{2}$ Vår förståelse ligger i linje med denna nyare inriktning i forskningen om barn som upplever våld i sin familj. Ambitionen är att behandla barn som subjekt, både i sina egna liv och i forskningen. ${ }^{3}$

\section{Omsorg och rättigheter}

En vilja att involvera barn i forskning och att se dem som subjekt och sociala aktörer utesluter dock inte att de kan behöva skydd och stöd från vuxna. Vi tar avstamp i Halldis Leiras (1990) diskussion om barns behov av att få sina upplevelser av våld i sin familj giltiggjorda. Ett kulturellt tabu mot att tala om våld i familjen gör enligt Leira att barn som upplever våld i sina familjer utsätts för tabuiserade trauman. ${ }^{4}$ Tabut innebär att barn som upplever pappas våld mot mamma får begränsade möjligheter att förstå och tolka det de varit med om. För att barnen ska kunna bearbeta det de varit med om och hitta strategier att hantera sin livssituation krävs att någon bekräftar och gör deras upplevelser giltiga. Alla vuxna

2 Om den "nya» barndomssociologin, se t.ex Alanen (1992), Alanen och Mayall (2001), James et al. (1998), Näsman (1994), Närvänen och Näsman (2007), Qvortrup (1994).

3 I övrigt kan vår teoretiska ansats på ett mer allmänt plan karaktäriseras som socialkonstruktionistisk, tolkande sociologi där kön och ålder kombineras i en intersektionell ansats, se Eriksson (2003), Krekula, et al. (2005).

4 Ett trauma kan något förenklat sägas vara en yttre händelse eller situation som är så skrämmande och påfrestande att den skapar olika psykiska och fysiska reaktioner hos barnet. Se t.ex. Terr (1991). 
som finns runt barnet har därmed ansvar för att bidra till att barnets upplevelser giltiggörs. Det gäller vare sig vi möter dessa barn i socialtjänsten eller som forskare. Vi menar att barns delaktighet kan bidra till att skapa förutsättningar för giltiggörande och i förlängningen för barns återhämtningsprocess efter upplevelser av våld (Eriksson \& Näsman 2007).

Delaktighet är en fundamental rättighet i barnkonventionen. Konventionen är visserligen inte inkorporerad som en lag $\mathrm{i}$ Sverige, men den svenska lagstiftningen ska ha anpassats till konventionen. Det betyder bland annat att barn har rätt till delaktighet $i$ alla processer som berör dem, även om konventionen begränsar möjligheten att påverka genom att barns åsikt ska "tillmätas betydelse i förhållande till barnets ålder och mognad" (artikel 12). Det innebär att barns kompetens ifrågasätts. Trots att den här typen av ifrågasättande återfinns i Föräldrabalken kan den dock sägas representera barnet som kompetent nog att få göra sin röst hörd och sin vilja beaktad (jfr. Singer 2000). Familjerättsutredare är ålagda att undersöka "barnets inställning" och redovisa den inför rätten (Föräldrabalken 6 kap. 19§). Sedan 2006 har barn också fått rätt att komma till tals redan i samband med interimistiska beslut om vårdnad, boende, eller umgänge (se Prop. 2005/06:99).

Tidigare studier visar dock att det här synsättet i många fall inte omsätts i praktiken (Dahlstrand 2004, Eriksson 2003, Höjer \& Röbäck 2007). Barns kompetens för delaktighet och värdet av deras uppfattning för beslutsfattandet ifrågasätts (Singer 2000). Detta ifrågasättande finns generellt i samhället i Sverige liksom många andra länder. Det finns en tvetydighet i synen på barn som å ena sidan objekt och å andra sidan aktörer. Jens Qvortrup talar om de två perspektiven på barn som "i vardande" (becoming) respektive "varande» (being), vilka lever sida vid sida (Qvortrup 1994). Tvetydigheten har också formulerats som en spänning mellan en välfärdsprincip som ser barn som ofullständigt socialiserade och beroende av vuxnas omsorg, beskydd och kontroll, gentemot ett befrielseperspektiv som ser barn som kreativa sociala och moraliska aktörer med förmåga att handla, samspela och påverka sin barndom (Neale 2002 s. 456).

Beteckningen välfärd för den första principen kan tolkas som att det finns en motsättning mellan välfärd och aktörskap, men är det nödvändigtvis så? Kan inte rätt till delaktighet istället ses som en del av det som ingår i välfärd? I svenska diskussioner om demokrati och välfärd definieras välfärd utifrån de resurser som individen kan disponera för att själv få kontroll över och kunna styra sitt liv (SOU 2000:1). Välfärd är då inte en motpol till rättigheter och aktörskap utan kan tvärtom sägas omfatta det. Vi har därför valt att kalla ett perspektiv som innebär ett behovsorienterat synsätt eller en välfärdsprincip där barn ses som objekt, för ett omsorgsperspektiv, vilket på ett tydligare sätt synliggör att det finns en maktrelation mellan omsorgsgivare och mottagare, en underordning av barn relativt vuxna. Enligt ett rättighets- eller delaktighetsperspektiv ses barnet som medborgare och därmed aktör. 


\section{Giltiggörande och delaktighet}

Vår utgångspunkt är att de två perspektiv som skisseras ovan - omsorgs- respektive rättighets/delaktighetsperspektivet - kan samverka i ett dubbelt förhållningssätt (se Eriksson \& Näsman 2007). När det gäller omsorgsperspektivet undersöker vi hur utredares bemötande skapat förutsättningar för giltiggörande av barns upplevelser av våld. Rättighets-/delaktighetsperspektivet operationaliseras med utgångspunkt i Roger Harts (1992) stege för barns delaktighet (se Eriksson \& Näsman 2007). De första tre stegen i Harts modell (»Manipulation", "Dekoration", "Symbol») omfattar ingen delaktighet. I det första manipuleras barn att delta i ett sammanhang utan att själva veta vad det går ut på. Dekoration kan illustreras med den välkända bilden av en politiker som lyfter upp ett litet barn på armen under ett valmöte. Barnet som symbolvärde inbjuds till ett sammanhang för att det ger ett bra intryck utåt sett, under sken av att få bli delaktig men tas inte på allvar och får inget inflytande. Det fjärde steget ("Anvisad, men informerad") ger en viktig förutsättning för delaktighet: barnet blir informerat om vad saken gäller, men steget omfattar inte något aktörskap i beslutsprocessen. Det kommer först på nästa steg ("Konsulterad och informerad") där barnet får utrymme att yttra sig. Även här begränsas dock delaktigheten genom att de vuxna initierat situationen och tar besluten. På nästa steg ("Beslutsfattande initierat av vuxna, delat med barn«) är initiativet fortfarande de vuxnas men barnet får delta i beslutet. Härnäst ("Initierat och styrt av barn") följer utrymme för barnet att ta initi- ativ och fatta beslut och högst upp kommer att barn kan ta initiativ och besluten fattas, som för medborgare i allmänhet, tillsammans med andra („Beslutsfattande initierat av barn, delat med vuxnau). Utifrån de här dimensionerna i Harts delaktighetsstege har vi undersökt vilken grad av delaktighet som erbjudits barn.

\section{Metod, material, analys}

Forskningsprojektet om utsatta barn som sociala aktörer i utredningar om vårdnad, boende eller umgänge bygger bland annat på tematiskt strukturerade individuella intervjuer med barn som varit med om en utredningsprocess och samtalat med utredare. I dessa intervjuer beskriver och tolkar barn med en pappa som är eller har varit våldsam mot mamman retrospektivt sitt möte med utredare och sitt deltagande $i$ processen. Vi har fått information från 17 barn, tio pojkar och sju flickor, i åldrar från åtta till 17 år. Av de 17 har tre nåtts via kontakter som arbetar professionellt med stöd till barn som upplevt våld, medan övriga 14 kontaktats utifrån tingsrättsdomar från åren 2003-06. Vi har vid tre tingsrätter runt om i landet sökt domar i tvister om vårdnad, boende eller umgänge där det funnits uppgift om våld från pappan mot mamman. Vi har valt ut barn som bor med sin mamma och vi har kontaktat dem via henne som boendeförälder. Förutom att det är fråga om barn som bor med sin mamma och att det funnits uppgifter om våld från pappa mot mamma har vi sökt efter barn i lämplig ålder (från skolåldern och uppåt), fall där det framgår att socialtjänsten genomfört 
en vårdnadsutredning samt fall där det inte finns omständigheter som talar emot kontakt. ${ }^{5}$ I vissa fall där vi tagit kontakt har barnens mamma och/eller barnen avböjt medverkan. Sammantaget betyder informantrekryteringen och urvalsförfarandet att barn med mycket svåra upplevelser av våld eller mycket problematiska myndighetskontakter kan vara underrepresenterade i materialet.

Så vitt vi kunnat bedöma representerar barnen en stor spännvidd i klasstillhörighet och en tredjedel har en eller två föräldrar med utomeuropeisk bakgrund. Deras våldserfarenheter sträcker sig från att ha sett och hört grovt fysiskt våld mot sin mamma och/eller själva ha blivit utsatta för fysiskt våld, till att framförallt ha upplevt psykiskt våld mot sin mamma i form av hot och trakasserier. Våra intervjuer skedde allt mellan två veckor och mer än två år efter deras möte med familjerätten. ${ }^{6}$ Av de 17 barnen har 14 intervjuats (en per telefon) och tre barn har valt att svara på våra frågor skriftligt $\mathrm{i}$ ett frågeformulär som bygger på intervjuguiden. De intervjuer som genomfördes ansikte mot ansikte spelades in och skrevs ut och vid telefonintervjun fördes anteckningar som sedan skrevs ut. Samtliga utskrifter

5 I vissa fall har det exempelvis framgått av domen att det är fråga om mycket utsatta barn eller så har barnen och deras mamma haft skyddade personuppgifter. I dessa fall har vi avstått från att ta kontakt.

6 Det senare gäller framförallt några av de äldre barnen. Vår bedömning är att tiden mellan utredningssamtalen och vår intervju inte har något samband med de mönster i materialet som presenteras i den här artikeln. har förmedlats till barnen för rättning och godkännande.

För att genomföra intervjuerna på ett etiskt rimligt sätt försökte vi under intervjuprocessens olika steg använda det dubbla förhållningssätt som bygger på både omsorgs- och rättighetsprincipen (se Eriksson \& Näsman 2008). Vi avstod att kontakta vissa mycket utsatta barn (se ovan). När vi valt ut barn att kontakta och deras mödrar hade givit sitt samtycke till barnens deltagande var nästa steg ett informerat samtycke från barnen själva. Vi bad först mödrarna att ge information till barnen och om barnen ville träffa oss, besökte vi dem hemma och berättade mer detaljerat om projektet, vad vi ville med det och vad det innebar att delta. Den här typen av praktiker är naturligtvis välkända för alla som arbetat med barn i forskning och de ligger i linje med rättighets/delaktighetsprincipen. Vi vill dock påpeka att $i$ vår muntliga information till barnen ingick någon form av indikation på att vi kände till historien med våld. Genom att informera barnen om att vi kände till att de har eller har haft en svår situation och har upplevt våld, och genom att även ge viss konkret information om vad vi visste, försökte vi få barnen att känna att de skulle kunna prata också om svåra upplevelser om de ville det. Vårt syfte var att skapa ett öppet medvetenhetssammanhang ("context of awareness") (Glaser \& Strauss 1964) och en delad definition av situationen (Schutz 1967) både när det gäller intervjusamtalens syfte och kunskapen om våldshistorien.

Under intervjuerna reflekterade vi löpande över de problem som skapas genom maktobalansen i barn-vuxenrelationen (se 
Eriksson \& Näsman 2008). Vi har även haft en beredskap för att förmedla kontakt till verksamheter som kan ge hjälp och stöd till barn som upplevt våld. Detta blev dock aldrig aktuellt, vilket kan ha med urvalsprocessen att göra.

\section{Analytiska ingångar}

De resultat som presenteras i den här artikeln bygger på en analys av materialet som helhet. Alla barn i informantgruppen citeras inte utan citaten är utvalda för att de på ett tydligt sätt illustrerar våra resonemang. Analysen bygger på vår generella tolkande och konstruktionistiska ansats och har fokus på de barnpositioner som konstrueras i samspel mellan familjerättsutredare och barn så som det framgår av barnens berättelser. De två centrala begrepp som organiserar presentationen av materialet och analysen har vuxit fram i en tolkningsprocess och vi betraktar dem som en del av våra resultat. Det första begreppet är bemötande, som handlar om barnets beskrivning och tolkning av utredarens perspektiv på barnet, vilket handlingsutrymme barnets erbjuds och i vilken mån barnet är i fokus för utredaren. Av bemötandet följer den sociala position barnen tillskrivs, vilken grad av delaktighet de får samt vilka dimensioner av delaktighet som är aktuella: att barnet får information, att barnet också konsulteras, att barnet tillåts vara med och fatta beslut samt att det finns utrymme för barnets egna initiativ. Vi vänder också på perspektivet och fokuserar barns beskrivningar av sitt eget agerande eller brist på sådant så som de framgår av deras berättel- ser. Även här är delaktighetsbegreppet centralt, liksom det mer övergripande aktörskap. Hur barnens handlande kan förstås i relation till deras avsikter och bedömningar av situationen fångas med begreppet stra tegi(se nedan).

\section{Utredares bemötanden: processen}

Barnens beskrivningar av de aspekter av utredares bemötanden som kan kopplas till den familjerättsliga processen kan placeras in i två olika kontinuum. Det första handlar om i vilken grad utredaren genom sina handlingar försökt öka graden av delaktighet för barnet, exempelvis genom sättet att informera och konsultera barnet. Den ena extremen innebär handlingar som öppnar för en hög grad av delaktighet för barn, den andra extremen handlingar som exkluderar barnet från delaktighet, ett förhållningssätt vi väljer att benämna »beskyddande». Det andra kontinuumet handlar om i vilken grad mötet mellan barn och utredare haft fokus på barnet, barnets vilja och perspektiv samt genomförts på ett sätt som varit anpassat till barn. Här utgörs den ena extremen av ett barnorienterat förhållningssätt och den andra av ett vuxenorienterat (se nedan). Då dessa dimensioner av bemötanden kombineras framträder olika barnpositioner (Figur 1, s. 27).

\section{Delaktigt barn}

Den första barnpositionen skapas av en kombination av ett barnorienterat förhåll- 
ningssätt och uttalade försök att öka barnets delaktighet i processen. Det är den position som lagstiftaren ser framför sig, ett delaktigt barn. I vårt material är det utsagorna från 13-åriga Annelie som tydligast illustrerar det här mönstret. ${ }^{7}$ I Annelies berättelse framställs utredaren som lyhörd och empatisk: "han var ganska, han var rätt okej, han hade egna barn och så, jag tycker att han visste hur man ska hantera... allså hur man skulle hantera barn och så巛. När det gällde själva sättet att samtala så framstår det som anpassat till att Annelie definieras som just »barn«. Enligt informanten har hon träffat utredaren utan mamma närvarande vid ett tillfälle:

Annelie: Ja, tror jag. Ja, då var det när vi lekte med typ... det var då med björnarna (skratt) [Intervjuaren: ja, ja]. [...] ${ }^{8}$

I: Men det här att prata om björnarna då, hur var det?

Annelie: Jag tycker det var ganska... alltså barnsligt. För det var typ kort med björnar på, som gjorde olika saker [just det] så skulle man få typ fã välja dom som har olika karaktärer till en person i familjen [just det], jag tycker det var väldigt barnsligt. Jag kunde ju helt enkelt berättat för honom istället.

Även om Annelie säger att själva samtalsmetoden är barnslig och alltså inte anpassad till just hennes ålder uttrycker hon sig överlag mycket positivt om mötet med

7 Alla informantnamn är fingerade.

8 I samtal med barn används ibland en kortlek med bilder på björnar som visar upp olika sinnestämningar och känslor. utredaren. Till skillnad från en stor del av de andra barnen i vårt material (inklusive en del av dem som är äldre än hon själv) beskriver Annelie också att hon fick se den text som utredaren skrivit efter sina möten med henne, samt andra delar av utredningstexten. I vår informantgrupp är hon ensam om att prata om så långtgående information.

\section{Beskyddat barn}

Vi har få exempel på det bemötande Annelie beskriver $i$ vårt material. Ett starkare mönster är att informanten framstår som ett beskyddat barn där utredarna skapat ett mycket begränsat utrymme för delaktighet i utredningsprocessen. De barn som ger den bilden beskriver också utredarna som empatiska och barnorienterade i samtalen, men barnen framstår snarare som objekt för vuxnas omsorg och beskydd, än som parter i målet: de har getts små möjligheter att påverka hur samtalen ska organiseras (tid och plats till exempel), de har fått lite information om vad samtalen egentligen går ut på, samt lite eller ingen återkoppling efter samtalen:

I: Så du fick egentligen inte veta hur hon skrev sedan?

Johan (9): Jag tror inte det.

I: Nej, okej. Skulle du ha velat se det?

Johan: (paus) $\mathrm{Nej}$

I: Att du visste vad hon skrev?

Johan: Eller jag visste inte vad hon skrev men ville ändå inte se det.

Som framgår av citatet ovan betyder en 
berättelse om detta bemötande inte nödvändigtvis att informanten är missnöjd. Vi har dock även exempel på barn som uttrycker en tydlig kritik mot att på olika sätt exkluderas från delaktighet, exempelvis genom att inte konsulteras om hur och när mötena med utredarna ska ske.

\section{Diskvalificeradvuxen}

Det andra tydliga mönstret $\mathrm{i}$ vårt material är beskrivningar av beskyddande när det gäller utredningsprocessen, kombinerat med ett mer vuxenorienterat förhållningssätt i själva samtalen. Den vuxenorientering som barnen berättar om handlar både om vems perspektiv, behov, eller känslor som stått i centrum i samtalet, och om samtalssituationen. För att börja med den första aspekten säger exempelvis ett av de barn i informantgruppen som inte vill träffa sin pappa att "allt handlade om min pappa, de sa han vill träffa dig, han har rätt att träffa digu. När det gäller den andra aspekten kan den illustreras av ett utdrag ur intervjun med åttaåriga Willow. Han beskriver en låg grad av delaktighet i processen och hans övergripande kommentar om att träffa utredarna är »tråkigt«:

I: Alltså, hade de kunnat göra på något sätt som hade varit bättre?

Willow: Nej

I: Bara att du var där var inte bra?

Willow: Nej det var tråkigt att vara hos dem.

Men hos [verksamhet för barn som upplevt våld] såär det roligt.

I: Vad är det som är bra där då?
Willow. Vi målar och fikar och...

I: Var det något du ville säga till dem?

Willow: Nej [nej]. De var ganska snåla. De bjöd bara på vatten.

Willow kontrasterar sitt möte med familjerättsutredarna mot sina erfarenheter av en verksamhet för barn som upplevt våld. Det som lyfts fram som positivt när det gäller den senare är aktiviteter och "fika». Mot den här bakgrunden blir familjerättsutredarnas vattenglas ett uttryck för deras "snålhet». Även andra exempel synliggör att "fika" kan symbolisera välkomnande och omsorg och därför kan vara en viktig del i barns upplevelser av möten med vuxna som något positivt. Vissa informanter förmedlar en bild av hur de förväntas kunna sitta still och samtala, vara fokuserade på ämnet för samtalet, inte göra för stora utsvävningar eller leka (ta för mycket eget initiativ), förväntas uppskatta det glas vatten som erbjuds, och så vidare. De har bemötts som om de vore vuxna. Då deras möjlighet till inflytande över samtalssituationen och processen samtidigt är minimal tydliggörs att den här barnpositionen

\section{Figur I.}

Utredares bemötanden: processen.

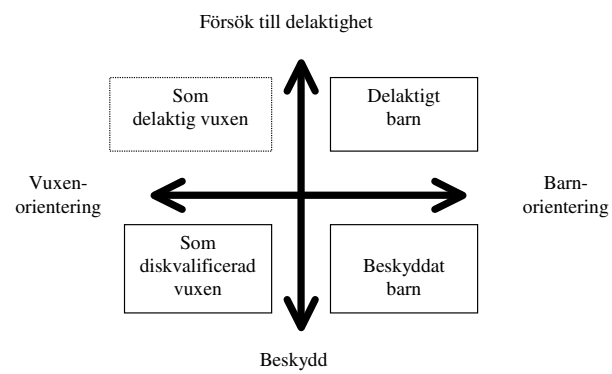


endast delvis innebär att bli behandlad som en vuxen deltagare i processen: barnet bemöts snarast som en diskvalificerad vuxen.

Logiskt sett är det möjligt att också föreställa sig att ett barn kan bemötas som en delaktig vuxen, det vill säga med handlingar som gör dem delaktiga i processen, samtidigt som själva förhållningssättet i samtalet är vuxenanpassat på det sätt som beskrivs ovan. En sådan barnposition framträder dock inte på något tydligt sätt i vårt material.

\section{Barns strategier}

Vår utgångspunkt är att barn är aktörer som uttolkar omvärlden och agerar i sina liv i samspel med andra. Utifrån det blir det viktigt att diskutera hur barnen förhållit sig till situationen och om de använde det handlingsutrymme de uppfattade att de hade. Vi prövar tanken att det som barnen gör i denna situation - som de alla i någon mån är förberedda på - har ett inslag av avsiktlighet som gör det rimligt att använda ett begrepp som strategi: handlande eller icke-handlande som är i någon mån valt utifrån en avsikt. Vilken avsikten varit kan $\mathrm{i}$ vissa fall utläsas genom barnens sätt att beskriva sitt agerande, i andra fall är det något vi får tolka in. Även här tar vi hjälp av ett par kontinuum som barnens handlingar och förhållningssätt kan placeras in i. Det första handlar om i vilken grad barnen beskriver att de accepterat hur utredningen har genomförts och sträcker sig från barnets accepterande medverkan i utredningen, över motvillig eller minimal medverkan till öppen protest mot hur utredningen och samtalen gått till. Ett andra kontinuum sträcker sig från beskrivningar av aktiva försök att åstadkomma en högre grad av delaktighet till beskrivningar av passivitet i meningen accepterande av sättet de blivit bemötta på (se Figur 2, s. 30).

\section{Vill vara delaktig}

Av vissa intervjuer framgår det att barnen accepterat utredningssamtalen och de beskriver samtidigt antingen hur utredarnas bemötande erbjudit dem en hög grad av delaktighet (som Annelie ovan) eller hur de själva på olika sätt försökt skapa en högre grad av delaktighet. Ett exempel på det senare är tioåriga Cathrine som beskriver hur hon under utredningssamtalet försökte kika över utredarens axel för att få se vad denna skrev i sin rapport från samtalet. Barnens vilja till delaktighet kan också handla om att de medverkar i utredningssamtalen av strategiska skäl, det vill säga för att uppnå något. Det kan handla om mål knutna till själva tvisten, som att tala om hur de vill bo, om och hur de vill träffa sin pappa, och så vidare. Det kan dock även handla om mer långsiktiga mål, exempelvis att förmedla ett budskap om rätten till egen autonomi till sin kontrollerande pappa. Barnets syfte kan med andra ord gå utöver själva den familjerättsliga processen och snarare handla om hela livssituationen och nära relationer. 


\section{Nöjd som objekt}

När accepterande medverkan i utredningen kombineras med att barnet även accepterar ett bemötande som innebär en låg grad av delaktighet i processen, tolkar vi det som att barnets tar positionen nöjd som objekt för vuxnas intervention. Ett barn som illustrerar den här positionen är Johan som vi citerar inledningsvis. Han beskriver å ena sidan en låg grad av delaktighet, samtidigt som han uttrycker sig väldigt positivt om hur han har bemötts.

\section{Missnöjd part}

Barnintervjuerna innehåller dock inte endast tal om hur barnen aktivt och villigt medverkat, utan även beskrivningar av olika grader av motstånd och protest. Motstånd och protester handlar både om att inte bli lyssnad på eller ha inflytande över själva samtalssituationen, och om möjligheter att komma till tals i den rättsliga tvisten. Ett exempel på det senare är 13-årige Mikael som berättar att han själv skrivit ett brev till domstolen för att på så sätt försöka föra fram hur han ville ha det (inte träffa sin pappa). Ett exempel på missnöje, motstånd och protest i själva samtalssituationen hittar vi i intervjun med tioåriga Rasmus:

Rasmus: Då dom kom hit första gången, [och] skulle prata med mig och dom sa att det var jag, att jag skulle känna mig trygg och att allt skulle handla om mig (paus) [mm] och inte om han (paus) [mm] och sen kom dom flera gånger och sa 'men han [har] sagt att han vill träffa dig och han har rätt att träffa dig för han är din pappa, han är din biologiska pappa', men då sa jag till dom att 'du sa att det var jag som skulle känna mig trygg och jag känner mig inte trygg för jag vill inte träffa honom'. 'Okej. Men du kan ju försöka lite'. Då sa jag nej. Så sa dom 'Okej vi kommer en annan gång'. [Dom] kommer [en] annan gång, sa att han vill träffa dig och han har rätt träffa dig. Dåbörjade dom [...] dom kom så många gånger, så att jag sa att okej jag kanske kan träffa honom, fast jag ville inte det.

I Rasmus berättelse refererar han utredarnas förklaringar om förutsättningarna för samtalet, visar sedan hur utredarna bryter emot dessa, och berättar att han påpekat detta för dem. I berättelsen är han en kritisk granskare av samtalen, argumenterar emot och säger nej, även om han också berättar hur han så småningom böjer sig för deras påtryckning. Den barnpositionen som Mikael och Rasmus tar kallar vi missnöjdpart $i$ målet.

\section{Ovilligeller otillgänglig}

Av vissa intervjuer framgår att barnet ifråga knappast kan karaktäriseras som att det accepterat att medverka i utredningen, även om de inte berättar om direkta försök att förändra hur utredningen eller samtalet gått till:

Martin (9 år): Jag vill helst inte gå dit

I: Du ville helst inte gå dit?

Martin: Nej. 
I: Nej, När du väl gick dit tyckte du då att det var okej att gå dit?

Martin: Lite

I: Lite, okej.

Martin: Jaa.

I: Skulle du helst ha sluppit?

Martin: Ja

I: Mm, tycker du att barn ska själva få bestämma vad dom ska bo och hur mycket dom ska träffa sin mamma och pappa?

Martin: Nej, bara när dom blir typ 12 kanske

I: 12 år. Så du tycker att du är för liten då?

Martin: Ja.

I: Vad är det som gör att du är för liten då? Varför kan du inte tycka, bestämma sådant? Martin: Därför att dom har sagt att eeehhh, dom har sagt att jag inte fär bestämma.

I: Du fär inte bestämma?

Martin: Varsjagskabo

I: Vadsa du?

Martin: Dom har sagt att jag inte fär bestämma vars jag skabo.

Martins kommentar om 12-årsgränsen gör det klart att han uppfattar att han har väldigt små möjligheter till inflytande över de beslut som påverkar hans liv. ${ }^{9}$ Hans ovilja att delta i samtal kan möjligen tolkas som en form av implicit protest mot att behöva prata med utredare när han ändå inte kan påverka något.

Positionen ovilligt eller otillgängligt barn

9 Regler om verkställighet i Föräldrabalkens 21 kapitel (gällde fram till juni 2006) som innebar att man inte verkställer en dom mot ett barns uttryckta vilja om barnet fyllt 12 år eller uppnått motsvarande mognadsgrad, har gjort att det i praxis utvecklats en "12-årsgräns" (jfr t.ex. Röbäck 2008). skapas då barn på olika sätt uttrycker sitt missnöje med hur utredningen eller samtalen går till, men samtidigt inte gör några aktiva försök att påverka situationen. Den här positionen är det närmaste vi kommer att barnet vägrat medverka i processen. Barn som vägrat medverka i den familjerättsliga utredningen är uteslutna ur studiens urval, men det är naturligtvis möjligt att tänka sig att vissa barn väljer detta som överordnad strategi. Samtidigt får barns möjlighet att helt slippa träffa utredare under exempelvis ett hembesök ses som begränsad. För barns del kan därför passivitet och tystnad ses som en form av implicit vägran att medverka.

\section{Utredares bemötanden: våldet}

I vilken grad har barnens egna tankar och känslor förknippade med våldet blivit föremål för dialog mellan barn och utredarna? Hur mycket information har barnet fått om det våld som utövats och om utredarnas kunskap om våldet? I vilken mån har våldet mot mamman - eller mot barnet - överhuvudtaget benämnts? Även här presenteras

Figur 2.

Barns strategier.

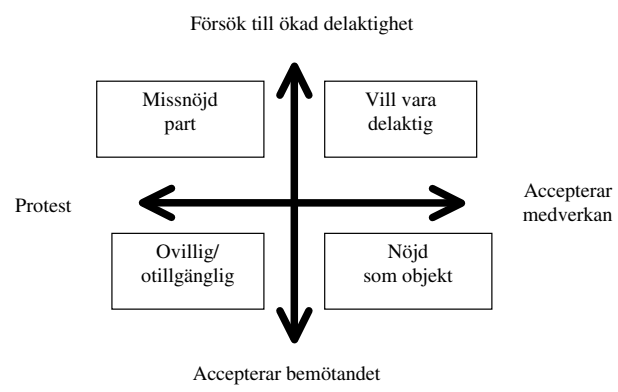


materialet och analysen med hjälp av ett par kontinuum: ett där den ena extremen utgörs av att våldet i relativt hög grad blivit en fråga för dialog mellan barn och utredare, och den andra extremen är att våldet inte benämnts överhuvudtaget. I det andra utgörs den ena extremen av en situation där barnet är skyddat från fortsatta upplevelser av våld (mot mamma och/eller mot sig själv), medan den andra extremen är att barnet fortsatt är utsatt på olika sätt (Figur 3, s. 34). Tolkningen av graden av skydd bygger i första hand på vad barnet ifråga själv säger, men vi har även tagit hänsyn till den information vi har tillgång till genom tingsrättsdomen och/eller barnets mamma.

\section{Beskyddat offer}

Vissa barn beskriver att de är skyddade från ytterligare upplevelser av våld. I en del fall har barnet inte längre kontakt med den våldsutövande pappan, i andra fall innebär kontakten med pappan inte fortsatta upplevelser av våld. Samtidigt säger barnen att de inte har pratat med utredarna om pappas våld mot mamma. Bland familjerättsutredare kan det finnas en föreställning om att man inte ska »dra in «barn i »föräldrakonflikter« utan barnen ska skyddas från att behöva ta ställning till det som pågår "mellan« föräldrarna (Eriksson 2003, Röbäck 2008). Den barnposition som framträder här är således ett beskyddat offer. En av de informanter som kan illustrera berättelser om det här bemötandet är Cathrine. Hon har inte pratat med utredarna om pappas våld mot mamma och säger om utredarna att »de ville nog inte fråga så här rakt påu.
Att barn kan uppleva positionen som beskyddat offer som problematisk illustreras av den pojke vi kallar Martin. Han har fått höra att han inte får bestämma över sin situation (se ovan). Samtidigt vill han gärna träffa sin pappa, är väldigt missnöjd och säger att han inte riktigt vet varför han inte får träffa pappan lika mycket som förut:

\section{I: Du vet inte varför det förändrades?}

Martin: Nej,

\section{I: Det är ingen som har berättat för dig?}

Martin: Eeh, nej.

I: $N e j$

Martin: På sätt och vis säkert för att jag ville för att det var en gång när jag skulle gå och lägga mig [mm] hörde jag pappa och [nya sambon] bråka, och du vet dom rör sig, kunde man höra vart dom än var kunde man.

I: Okej, då tyckte de inte att dom var så bra att du bodde så mycket hos din pappa?

Martin: Äh,jag tror det.

De vuxna runt omkring Martin tycks ha sett hans utsatthet och försökt skydda honom från fortsatta upplevelser av våld (inte längre i form av pappas våld mot mamma utan nu mot pappans nya sambo). Samtidigt har det här temat inte diskuterats tillräckligt mycket för att Martin ska ha helt klart för sig varför beslutet i den rättsliga tvisten blivit som det blivit, varför han ska träffa sin pappa mindre än han själv vill. Han har en egen tolkning, att det har att göra med pappans våld, men enligt honom själv är det inget han fått förklarat för sig. En låg grad av delaktighet, utan tillräcklig information om de omständigheter som ligger till grund för rättens beslut, kan göra både besluten 
och livssituationen svårbegripliga för de berörda barnen.

\section{Osynligt offer}

Andra barn beskriver handlingar och förhållningssätt som snarast gör den egna upplevelsen av våld osynlig, trots att barnet befinner sig i en fortsatt utsatt situation. Ett exempel är Rasmus. Enligt honom var pappans våld inte ett centralt samtalsämne under hans möten med utredarna och de ifrågasatte till och med om han verkligen kom ihåg pappans våld. I stället pratade de om ovidkommande saker: "så började han prata om gympa, skolan och prata om sådana här saker, jag tänkte men sa inte, varför pratar du om sådana här saker?". Resultaten av den familjerättsliga utredningen blev att Rasmus var tvungen att träffa den pappa han var rädd för. Därmed försattes han i en situation som utifrån barnets beskrivning närmast kan karaktäriseras som psykiskt våld:

Rasmus: ... första gången efter det jag träffade honom började jag må illa, började få ont $i$ magen, jag gick på toan jag kräktes, fast dom kom igen för dom brydde sig inte hur jag mådde [nej] nej om jag mådde bra, om jag mådde dåligt skulle jag ändå gå dit. Även om jag mådde dåligt skulle jag ändå gå dit. Jag kunde ha ont i magen, jag kunde må illa, jag kunde [...] det kunde va vad som helst, fast dom sa att 'du ska ändå gå dit'.

När barnets upplevelse av och känslor förknippade med det våld som förekommit förblir osynliga eller ogiltiggörs och våldet (inklusive dess konsekvenser) inte blir föremål för dialog mellan barn och utredare samtidigt som barnet fortsatt befinner sig i en utsatt situation, då påtvingas barnet positionen osynligt offer.

\section{Oskyddat offer}

När Rasmus beskrivningar av sitt eget agerande tas med i analysen blir det dock inte helt rättvisande att karaktärisera den position han tagit som "osynligt" offer. Under intervjun återkommer det här barnet till hur han har försökt få fram till vuxna runt honom att han är rädd för sin pappa. Den position Rasmus beskriver framstår därför snarast som oskyddat offer: hans fortsatta utsatthet var synlig för vuxna runt om honom. I Rasmus fall framgår det klart att hans rädsla blev känd för socialtjänstens personal, men i vilken grad hans utsatthet varit föremål för dialog med familjerättsutredarna är svårare att utläsa av intervjun. I Johans fall däremot är detta tydligt:

I: Kommer du ihåg vilka frågor hon ställde, vad hon frägade om?

Johan: Jag kommer ihåg att hon frågade hur jag mådde och det men [mm] det var väl också vem jag ville vara med och vem jag tyckte mest om [jaa]. Ja allså inte vem jag var sur på, på det där sättet men jag sa att jag tyckte mest om mamma [mm] för hon brukar inte slå mig. Hon slår mig aldrig. I: Mm. Hur tyckte du det kändes att sitta där och prata med henne om din mamma ochpappa? 
Johan: Det kändes skönt att säga det till någon som jag litar på.

Johan beskriver hur han berättat för utredaren att hans pappa även slagit honom. I intervjun bekräftar Johan att utredaren hade tagit upp frågan om pappans våld mot mamma under samtalet med honom, och även att han själv sagt till utredaren att han är rädd för sin pappa. Trots att våldet mot både mamma och barn, och barnets rädsla, var känt gjordes uppenbarligen för lite för att skydda Johan. Lite senare i intervjun berättar han om upprepat våld mot sig själv, som en direkt konsekvens av den familjerättsliga utredningen:

I: Du säger att du litade på henne [utredaren], var du på något sätt rädd att din mamma eller pappa skulle få redapå vad du hade sagt?

Johan: Jag var rädd för att min pappa skulle göra det för när han fick se papprena om vad jag hade sagt så blev han arg och slog mig då också.

När utredare å ena sidan gör våldet synligt men sättet att hantera barnets situation, å andra sidan, innebär att barnet förblir oskyddad eller utsätts igen, skapas barnpositionen oskyddat offer.

Den här positionen kan tolkas och hanteras på olika sätt av barn. Medan Rasmus tycks uppfatta den barnposition han erbjudits som oacceptabel och förväntar sig att bli bemött på ett annat sätt kan vi i Johans fall inte göra en så entydig tolkning av barnets förståelse av det "budskap" som finns inbyggt i positionen oskyddat offer: "vi vet att du är utsatt, men skyd- dar dig inte ändåı. När Johan längre fram i intervjun får en fråga om vad han tycker om utredningens resultat när det gäller boende och umgänge tolkar han frågan på ett lite annat sätt än vad intervjuaren tänkt sig:

I: $M m$, tycker du att det fungerar som det harblivit?

Johan: Att han har slagit mig och det?

I: Nej, inte att han har slagit dig för det ska han naturligtvis inte göra. Jag tänker sedan efter det att domstolen bestämt hur det ska vara för dig med att träffa din pappa och så.

Johans tolkning av intervjufrågan kan förstås som att för honom är det inte självklart att våldet är oacceptabelt: det är något man kan tycka olika saker om. Det här citatet synliggör de etiska krav som ställs vid intervjuer med utsatta personer överhuvudtaget och i synnerhet $i$ intervjuer med utsatta barn (se ovan och Eriksson \& Näsman 2008). Ett förhållningssätt med ett fokuserat och engagerat lyssnande ger i sig ett budskap om empati och bekräftelse. Det räcker långt med hummanden och nickar, också när barn berättar om erfarenheter av våld. Vi valde dock att ibland (som ovan) uttrycka en klar ståndpunkt och att vissa handlingar är oacceptabla. Detta var fallet i situationer där ett neutralt lyssnande skulle kunna upplevas som att vi accepterar det vuxenbeteende som barnet beskrev. Den här typen av kommentarer från oss som intervjuare är som vi ser det en del av giltiggörandet av upplevelser av våld. 


\section{Offer-med delaktighet}

För att barns upplevelser ska giltiggöras som våld och som något oacceptabelt, krävs för det första att barnets erfarenheter av våld och känslor och tankar förknippade med det blir föremål för en dialog med utredarna. För det andra krävs att deras situation hanteras på ett sådant sätt att de skyddas från ytterligare utsatthet. I vårt material finns ett exempel där barnet relativt tydligt beskriver den här typen av bemötande: Annelie. Hon är skyddad från ytterligare utsatthet. Även om hon inte går in $\mathrm{i}$ detaljer $\mathrm{i}$ vår intervju beskriver hon att hon pratat med utredaren om pappans beteende och om vad hon tänker och känner inför det. Den barnposition som framträder ur den här intervjun är med andra ord ett offer med delaktighet-delaktighet i meningen att ha varit i dialog med utredare om sina upplevelser och känslor och med information om utredarens kunskap om våldet.

\section{Figur 3.}

Utredares bemötanden: våldet.

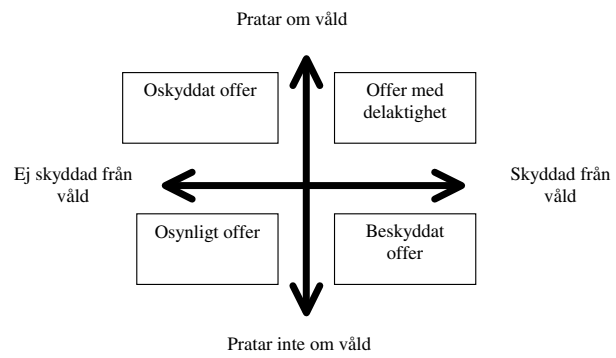

\section{Utsatta barn som aktörer?}

De positioner som vi diskuterar i den här artikeln är analytiska konstruktioner. De bygger på ett empiriskt material men är inte i första hand beskrivningar av konkreta informanter. Vissa av de enskilda barnen beskriver ett bemötande eller strategier som ligger nära en specifik position, medan andra intervjuer inte alls ger en lika renodlad bild. Med detta sagt kan vi ändå konstatera att det tycks finnas en relation mellan det bemötande barnet beskriver, och barnets egna strategier. Vi kan inte göra entydiga uttalanden om vad som kommit först utan det vi framförallt kan göra är att peka på samband. När det gäller utredningsprocessen är den övergripande tendensen att barnen beskriver bemötanden som positionerar dem som beskyddat barn eller diskvalificerad vuxen. De tenderar alltså inte att beskriva den typ av bemötande som lagstiftaren tänkt sig. Vidare är det de barn som beskriver ett bemötande som positionerar dem som antingen delaktigt barn eller beskyddat barn som tenderar att även beskriva hur de accepterar medverkan i utredningsprocessen. Beskrivningar av att vara motvillig, otillgänglig eller öppet protestera och aktivt försöka förändra sin situation tenderar att sammanfalla med beskrivningar av hur barnet bemötts som en diskvalificerad vuxen. Att varken få vara delaktig eller få beskyddande och empatisk omsorg från vuxna framstår därför som det mest problematiska ur våra barninformanters perspektiv.

När det gäller pappans våld mot mamma - och i vissa fall våld mot barnet - är det 
starkaste mönstret att barnen bemötts som beskyddade offer, osynliga offer, eller till och med oskyddade offer. Att vi överhuvudtaget har exempel på att barnet fortsättningsvis befunnit sig i en utsatt situation trots att barnets upplevelse av våld blivit föremål för dialog mellan barn och utredare är oroväckande. Vi noterar också att medan vissa barn uppfattar det som oacceptabelt att inte få skydd, ifrågasätter andra barn inte lika tydligt det budskap som är inbäddat i den här positionen: att det är tillåtet för pappa att utsätta barnet och att barnet inte kan förvänta sig skydd från andra vuxna.

Ur barns perspektiv kan det vara problematiskt att bli beskyddad från kunskap om våldet så till den grad att rättens beslut och den egna situationen framstår som obegriplig (beskyddat offer) eller att den egna utsattheten inte blir synlig (osynligt offer). Än mer problematiskt är det att bli synlig som offer utan att få skydd. Det enda tydliga exempel vi har på positionen offer med delaktighet är inte förknippat med vare sig implicit eller explicit protest från barnets sida. Utredarna tycks dock ha haft svårast att få till den typ av bemötande som - sett utifrån det här materialet - framstår som mindre problematiskt ur barns perspektiv: att både se och giltiggöra barnens utsatthet och samtidigt erbjuda dem delaktighet i utredningsprocessen. Att bemöta utsatta barn som offer och aktörer framstår både som en möjlighet och en utmaning för vårdnads-, boendeoch umgängesutredare.

\section{Referenser}

Alanen, Leena (1992) Modern Childhood? Exploring the 'child question' in sociology. Jyväskylä: Institute for Educational Research.

Alanen, Leena \& Mayall, Barry (red.) (2001) Conceptualising Child-Adult Relations. London: Routledge.

Cater, Åsa Källström (2004) Father's violence against mother - negotiating normality and deviation from children's perspectives. Örebro: Örebro universitet.

Cederborg, Ann-Christine \& Karlsson, Yvonne (2001) "Omhändertagande med barnets perspektiv«. Socialvetenskaplig tidskrift, nr. 3 s. 163-179.
Christensen, Else (2002) „En opvækst hvor mor bliver mishandlet - fra barnets synsvinkel«. I M. Eriksson, A. Nenola \& M. M. Nilsen (red.) Kön och våld $i$ Norden. Köpenhamn: Nordiska Ministerrådet, TemaNord 2002:545.

Dahlstrand, Lotta (2004) Barns deltagande i famil jerättsliga processer. Uppsala: Juridiska institutionen.

Eriksson, Maria (2003) I skuggan av Pappa. Famil jerätten och hanteringen av fäders våld. Stehag: Förlags AB Gondolin.

Eriksson, Maria (red.) (2007) Barn som upplever vaild. Nordisk forskning och praktik. Stockholm: Gothia Förlag. 
Eriksson Maria, Cater Åsa, Dahlkild-Öhman Gunilla \& Näsman Elisabet (red.) (2008) Barns röster om våld - Att tolka och förstå. Malmö: Gleerups.

Eriksson, Maria \& Näsman, Elisabet (2007) „Delaktighet i familjerättsprocesser för barn som upplevt pappas våld mot mammau. Socionomens forskningssupplement nr. 22, s. 78-89.

Eriksson, Maria \& Näsman, Elisabet (2008) »Intervjuer och barns delaktighet». I M. Eriksson, ^. K. Cater, G. Dahlkild-Öhman \& E. Näsman (red.) Barns röster om våld - Att tolka och förstå. Malmö: Gleerups.

Eskonen, Inkeri (2005) „Violence in children's narration". The International Journal of Child \& Family Welfare, vol. 8, nr 1, s. 32-45.

Forsberg, Hannele (2005) »Talking feels like you wouldn't love Dad anymore - Children's emotions, close relations and domestic violence». I M. Eriksson, M. Hester, S. Keskinen \& K. Pringle (red.) Tackling men's violence in families. Nordic Issues and Dilemmas. Bristol: Policy Press.

Glaser, Barney G. \& Strauss, Anselm L. (1964) "Awareness Contexts and Social Interaction". American Sociological Review, vol. 29. nr 5, s. 669-679.

Hart, Roger (1992) Children's participation: - from tokenism to citizenship. Firenze: UNICEF international Child Development Centre: 41.

Höjer, Ingrid \& Röbäck, Karin (2007) Barn i kläm - hur uppmärksammas barn i mål om verkställighet av umgänge. Stockholm: Allmänna Barnhuset.

James Alison, Jenks Chris \& Prout Alan (1998) Theorizing Childhood. Cambridge: Polity Press.

Krekula Clary, Närvänen Anna-Liisa \& Näsman Elisabet (2005) "Ålder i intersektionell analys". Kvinnovetenskaplig tidskrift, nr 2-3, s. 81-94.

Leira, Halldis K. (1990) „Fra tabuisert trauma til anerkjennelse og erkjennelse. Del I: Om arbeid med barn som har erfart vold i familjen. Del II: En modell for intervensjon med barn og unge som har erfart vold i familjen«. Tidsskrift for
Norsk Psykologforening, vol. 27, s. 16 -22 och s. 99- 105.

Mattsson, Titti (1998) „Barnets mening i LVUprocessen". Socialvetenskaplig tidskrift, nr 1, s. $45-57$.

Neale, Bren (2002) "Dialogues with Children. Children, divorce and citizenship». Childhood, vol. 9, nr 4, s. 445-475.

Närvänen, Anna-Liisa \& Näsman, Elisabet (2007) "Age order and children's agency". I H. Wintersberger, L. Alanen, T. Olk \& J. Qvortrup (red.) Childhood, Generational Order and the Welfare State: Exploring Children's Social and Economic Welfare. Odense: University Press of Southern Denmark.

Näsman, Elisabet (2004) „Barn, barndom och barns rätt». I L. Olsen, (red) Barns makt. Uppsala: Iustus förlag.

Qvortrup, Jens (1994) „Childhood Matters: An Introduction". I J. Qvortrup, M. Bardy, G. Sgitta \& H. Wintersberger (red.) Childhood Matters. Social Theory, Practice and Politics. Aldershot: Avebury.

Proposition 2005/06:99. Nya vårdnadsregler. Stockholm: Fritzes offentliga publikationer.

Rejmer, Annika (2003) Vårdnadstvister. En rättssociologisk studie av tingsrätts funktion vid handläggning av vårdnadskonflikter med utgaingspunkt frän barnets bästa. Lund: Lunds universitet, Lund Studies in Sociology of Law 16.

Röbäck, Karin (2008) »Barns vilja i verkställighet av umgängestvister«. I M. Eriksson, A. K. Cater, G. Dahlkild-Öhman \& E. Näsman (red) Barns röster om våld - Att tolka och förstå. Malmö: Gleerups.

Schutz, Alfred (1967[1932]) The Phenomenology of the Social World. Everton: Northwestern University Press.

Singer, Anna (2000) Föräldraskap i rättslig belysning. Uppsala: Iustus förlag.

Socialstyrelsen (2006) Individ- och familjeomsorg Lägesrapport 2005. Stockholm: Socialstyrelsen, Lägesbeskrivningar 2005.

Socialstyrelsen (2008) Familjerätt år 2007. Stockholm: Socialstyrelsen, Statistik Socialtjänst 2008:3. 
Solberg, Anne (2007) "Hur förhåller sig barn till våld i hemmet?" I M. Eriksson (red.) Barn som upplever våld. Nordisk forskning och praktik. Stockholm: Gothia Förlag.

SOU 2000:1 En uthällig demokrati. Politik för folkstyrelse på 2000-talet. Demokratiutredningens betänkande. Stockholm: Fritzes offentliga publikationer.

SOU 2005:43 Vårdnad - boende - umgänge: bar- nets bästa, föräldrars ansvar. Betänkande av 2002 års vårdnadskommitté. Stockholm: Fritzes offentliga publikationer.

Terr, Leonore C. (1991) „Childhood Traumas: An outline and overview". American Journal of Psychiatry, vol. 148, nr 1, s. 10-20.

Warming, Hanne (2002) Det er lidt svoert - men jeg må jo sige min mening. København: Frydenlund.

\section{Summary}

\section{Vulnerable children in family law proceedings Investigators' approaches and children's strategies}

Since the early 1990s a chain of law reforms have been passed with the intention of increasing children's participation in family law proceedings. Based upon a study of vulnerable children as social actors in family law proceedings, this article explores family law investigators' approaches to children, and children's strategies in encounters with investigators as well as the investigation process as a whole. The discussion is based upon thematically structured interviews with children whose father has been violent to their mother. The different kinds of investigator approaches that can be reconstructed from the children's narratives range from an empathetic and child-oriented approach to a distant, adultoriented one disqualifying the child as participant in the process and as victim of violence. Children's strategies span from accepting cooperation in the process, to unwilling cooperation, to open protest and attempts to achieve a higher degree of participation in the process. Most com- monly, children have been approached as a "protected child" or a "disqualified adult». The informants' descriptions of themselves as unwilling, unavailable, or openly protesting tend to coincide with the latter position: to get neither influence over the investigation process nor care and empathy seems to be the most problematic position from children's point of view. As regards children's experiences of violence, these have rarely been a topic for dialogue between child and investigator. The children have mainly been approached as 'protected victims', 'invisible victims' or even 'unprotected victims' when the children's own victimization has become visible to investigators but the children are left without protection. Drawing upon this sample of informants, we suggest that the most challenging task for family law investigators seems to be to make children's vulnerable position visible and at the same time offer them a high degree of participation: to approach them as victims and actors. 